\title{
Extraction of bioactive compounds from juçara pulp (Euterpe edulis M.) is affected by ultrasonic power and temperature
}

\section{Temperatura e potência ultrassônica afetam a extração de compostos bioativos da polpa de juçara (Euterpe edulis M.)}

\author{
Marina Carvalho Martins Madalão' (D), Emília Maria França Lima' ${ }^{(D)}$, Daiane Bonizioli Benincá1 (D), \\ Sérgio Henriques Saraiva ${ }^{1}$ (D) Raquel Vieira de Carvalho' ${ }^{1}$ (D) Pollyanna Ibrahim Silva ${ }^{1 *}$ (i)
}

'Universidade Federal do Espírito Santo/UFES, Centro de Ciências Agrárias e Engenharias, Departamento de Engenharia de Alimentos, Alegre, ES, Brasil

*Corresponding author: pollyannaibrahim@gmail.com

Received in September 11, 2020 and approved in February 16, 2021

\begin{abstract}
Anthocyanins and phenolic compounds from fruits and vegetables can be extracted using emerging technologies such as ultrasound-assisted extraction. This study aimed to investigate the effect of temperature and ultrasonic power on the extraction of anthocyanins, phenolic compounds from the extracts of juçara pulp (Euterpe edulis M.). We also determined the antioxidant capacity of the extract and determined characteristics of the pulp. Bioactive compounds were extracted in an ultrasonic bath ( 25 $\mathrm{kHz})$ at various temperatures $\left(25,32,39,46,53^{\circ} \mathrm{C}\right)$ and ultrasonic power $(0,360,900 \mathrm{~W})$. Juçara pulp had high total anthocyanin and phenolic content ( $298.86 \pm 27.68 \mathrm{mg}$ cyanidin-3-glucoside/100 g and $1226.39 \pm 21.08 \mathrm{mg}$ GAE/100 $\mathrm{g}$ on a wet basis, respectively). Cyanidin-3-rutinoside was the major anthocyanin in the extract, followed by cyanidin-3-glucoside, which were identified and quantified by high-performance liquid chromatography. For obtaining extracts rich in anthocyanins and phenolic compounds, we suggest that the extraction process should be performed at $25^{\circ} \mathrm{C}$ without the application of ultrasonic waves. However, to obtain extracts with outstanding antioxidant capacity, an ultrasonic power of $360 \mathrm{~W}$ at a frequency of $25 \mathrm{kHz}$ and a temperature of $25^{\circ} \mathrm{C}$ should be used.
\end{abstract}

Index terms: Anthocyanins; antioxidant capacity; characterization; phenolic compounds; ultrasound-assisted extraction.

\begin{abstract}
RESUMO
A extração de antocianinas e compostos fenólicos de frutas e vegetais pode ser realizada usando tecnologias emergentes, como o ultrassom. O objetivo deste estudo foi avaliar a influência da temperatura e da potência ultrassônica na extração de antocianinas, compostos fenólicos e capacidade antioxidante dos extratos da polpa de juçara (Euterpe edulis M.), além de realizar a caracterização da mesma. A extração dos compostos bioativos foi realizada em banho ultrassônico ( $25 \mathrm{kHz}$ ) com variação da temperatura $(25,32,39,46$, $53^{\circ} \mathrm{C}$ ) e potência ultrassônica $(0,360,900 \mathrm{~W})$. A polpa de juçara apresentou alto teor de antocianinas e fenólicos totais $(298,86 \pm 27,68$ mg de cianidina-3-glicosídeo/100 g e 1226,39 \pm 21,08 mg AGE/100 g em base úmida, respectivamente). Cianidina-3-rutinosídeo foi a principal antocianina presente no extrato, seguida pela cianidina-3-glicosídeo, identificadas e quantificadas por meio de cromatografia líquida de alta eficiência. Com relação aos ensaios de extração, para obtenção de extratos ricos em antocianinas e compostos fenólicos, sugere-se que o procedimento seja realizado a $25^{\circ} \mathrm{C}$ sem aplicação de ondas ultrassônicas. Porém, para obter extratos com excelente capacidade antioxidante, deve-se utilizar potência ultrassônica de $360 \mathrm{~W}$ a uma frequência de $25 \mathrm{kHz}$ e temperatura de $25^{\circ} \mathrm{C}$.
\end{abstract}

Termos para indexação: Antocianinas; capacidade antioxidante; caracterização; compostos fenólicos; extração assistida por ultrassom.

\section{INTRODUCTION}

The juçara palm (Euterpe edulis Martius), belonging to the family Arecaceae, is native to the Brazilian Atlantic Forest (Barroso et al., 2019) and can be found in the entire region starting from southern Bahia to the coast of Rio
Grande do Sul (Silva et al., 2013). Its fruits are called juçara and have characteristics similar to açaí, the fruits of Euterpe oleracea Martius and Euterpe precatoria Martius, produced in the Amazon region (Barroso et al., 2019; Inada et al., 2015). However, juçara has a sweeter taste than these two similar fruits and is thus a commercial fruit appreciated 
by consumers (Garcia et al., 2019). Juçara is a round fruit with a single seed that contributes to up to approximately $70 \%$ of the mass of the fruit (Oliveira, 2002). This seed is covered by a thin, dark purple bark that can appear almost black because of the high concentration of anthocyanins (Garcia et al., 2019).

Anthocyanins are phenolic compounds of the flavonoid class (López et al., 2018). They are natural pigments that, in addition to not having negative effects on health, such as those caused by some artificial pigments (Chen et al., 2017), confer protection against various diseases because of their antioxidant capacity (Jiang et al., 2020; Qin et al., 2018), and anti-inflammatory (Oliveira; Costa; Rocha, 2015), anticarcinogenic (Hogan et al., 2010; Priprem et al., 2017), and cardioprotective properties (Abdel-Moemin, 2011), which have been largely confirmed in vitro. Moreover, anthocyanins are also used as natural food colorants (Garcia et al., 2019; Lima et al., 2019a; Saito et al., 2019).

Anthocyanins can be extracted from fruits and vegetables via different methods such as conventional extraction (Bonfigli et al., 2017; Kobi et al., 2018; Lima et al., 2019b), which uses only solvents, microwave extraction (Garofulić et al., 2013), supercritical carbon dioxide (Brunner, 2005), pulsed electric field (Puértolas et al., 2013), and ultrasound (Albuquerque et al., 2020; Celli et al., 2015; Ivanovic et al., 2014; Mane et al., 2015). The conventional solvent extraction process for anthocyanin extraction is associated with long extraction times, high consumption of solvents, and low extraction efficiency (Bonfigli et al., 2017). Therefore, emerging technologies such as ultrasound-assisted extraction (UAE) seem to be promising options, which can be used for extracting compounds from different sources (Fernandes et al., 2020; Jin et al., 2019; Porto; Porretto; Decorti, 2013).

Ultrasound is a mechanical wave that operates in the frequency range between $20 \mathrm{kHz}$ and $1 \mathrm{GHz}$ and propagates through solid, liquid, and gaseous media. It has been used to extract various organic compounds, including phenolic compounds, from several different matrices (Carrera et al., 2012; Corbin et al., 2015; Jin et al., 2019). Thus, ultrasound can be considered a good alternative for improving the extraction of anthocyanins because of increased mass transfer rates and the possibility of rupturing of the cell wall during the cavitation process, which can lead to greater extraction (Bonfigli et al., 2017; Fernandes et al., 2020; López et al., 2018; Porto; Porretto; Decorti, 2013; Shirsath; Sonawane; Gogate, 2012). UAE is considered a promising technique as it offers many advantages: simple manipulation (Jin et al., 2019), low cost of equipment (Carrera et al., 2012), higher extraction yield efficiency in terms of time and solvent consumption (Adjé et al., 2010; Ivanovic et al., 2014), reduced energy and water consumption (Pinela et al., 2019), and use in low temperatures that can avoid thermal damage to extracts; thus, minimizing the loss of bioactive compounds (Bonfigli, et al., 2017; Corbin et al., 2015). The efficiency of this technique is affected by the process variables of temperature and ultrasonic power (Pinela et al., 2019), and therefore, optimizing these variables is important.

Hence, we aimed to evaluate the effect of temperature and ultrasonic power on the extraction process of juçara rich in anthocyanins and phenolic compounds and with high antioxidant capacity.

\section{MATERIAL AND METHODS}

\section{Raw material}

Frozen juçara (Euterpe edulis Martius) pulp was obtained from farmers in the Caparaó region of southern Espírito Santo State, Brazil (Latitude: $20^{\circ} 51^{\prime} 49^{\prime \prime}$ south, Longitude: $40^{\circ} 56^{\prime} 10^{\prime \prime}$ west) in February 2016. The pulp samples were stored at $-20{ }^{\circ} \mathrm{C}$ until the extraction tests were performed.

\section{Physicochemical characterization of juçara pulp}

The pulp was characterized three times and in triplicate. Data are expressed as mean \pm standard deviation on a wet basis.

\section{pH and total titratable acidity}

The $\mathrm{pH}$ of juçara pulp samples was determined using a digital $\mathrm{pH}$-meter (DEL LAB, DLA, Brazil) with the electrode inserted directly into the sample. Total titratable acidity in the juçara pulp samples was determined by titration with $0.1 \mathrm{M} \mathrm{NaOH}$. The results are expressed as the percentage of citric acid.

\section{Composition analysis}

Moisture, and lipid, ash, and protein content were analyzed according to the analytical standards of the Association of Official Analytics Chemists (Association of Official Analytics Chemists - AOAC, 2016). Moisture content was determined by gravimetric analysis after drying the samples in an oven at $105^{\circ} \mathrm{C}$ (Biopar, Brazil) until a constant weight was reached. Lipid content was determined by direct extraction using a Soxhlet extractor (Marconi, MA-491, Brazil) and petroleum ether as the solvent. Ash content was determined by incineration of 
the samples in a muffle furnace at $550{ }^{\circ} \mathrm{C}$ (Stecno - 115 , Brazil). Total nitrogen content was determined using the modified Kjeldahl method, which is based on the acid digestion of the sample followed by distillation using a nitrogen distiller (Marconi MA-0,36, Brazil) and titration. The nitrogen content value was multiplied by a factor of 6.25 to determine the protein content. Carbohydrate content was calculated by subtracting the total percentage of protein, lipids, moisture, and ash from 100.

\section{Bioactive compound quantification}

\section{Total anthocyanin extraction}

Total anthocyanins from the juçara pulp samples were extracted using $70 \%$ ethanol acidified with $\mathrm{HCl}$ to a $\mathrm{pH}$ of 2.0, according to the method described by Francis (1982), at $8 \pm 2{ }^{\circ} \mathrm{C}$ in darkness. The pigment was quantified by the differential $\mathrm{pH}$ method based on the procedure described by Giusti and Wrolstad (2001). To calculate the anthocyanin content, the original extract was diluted, and the results were expressed in terms of the quantity of cyanidin-3-glucoside ( $449.2 \mathrm{~g} / \mathrm{mol}$ molar mass). The molar absorptivity coefficient of $26,900 \mathrm{~L} / \mathrm{cm}$.mol was used, and absorption was measured at a wavelength of $510 \mathrm{~nm}$ using a spectrophotometer (BEL photonics; SP 2000 UV, Brazil).

\section{Identification of the main anthocyanins in the juçara pulp samples}

Anthocyanins from the juçara pulp were extracted using a solution of $50 \%$ methanol $(\mathrm{v} / \mathrm{v})$ and $37 \% \mathrm{HCl}$ $(\mathrm{v} / \mathrm{v})$ in a Dubnoff reciprocal shaking water bath for $2 \mathrm{~h}$. After extraction, the samples were centrifuged and frozen at $-18{ }^{\circ} \mathrm{C}$ until further analysis. The chromatographic analysis procedure was adapted from the method described by Schauss et al. (2006), in which a high-performance liquid chromatographic system coupled with a diode array detector (HPLC-DAD) (Shimadzu, SCL 10AT VP, Japan) was used, and detection was performed at $520 \mathrm{~nm}$. The mobile phase was an aqueous solution of acetonitrile $(89: 11 \mathrm{v} / \mathrm{v})$ adjusted to $\mathrm{pH} 2.0$ with formic acid. The flow rate was $1.0 \mathrm{~mL} / \mathrm{min}$, and the running time was $45 \mathrm{~min}$. A C18 column (Phenomenex Gemini, $250 \times 4.6 \mathrm{~mm}, 5 \mu \mathrm{m}$ ) equipped with a guard column (Phenomenex ODS C18, $4 \mathrm{~mm} \times 3 \mathrm{~mm}$ ) was used, and cyanidin-3-glucoside and cyanidin-3-rutinoside (Sigma-Aldrich, Germany) were used as standards.

\section{Total phenolic content (TPC)}

TPC was determined by the Folin Ciocalteu reagent assay using a method adapted from Singleton and Rossi (1965). A 3.0-mL volume of dilute FolinCiocalteu reagent $(1: 10 \mathrm{v} / \mathrm{v})$ was mixed with $0.6 \mathrm{~mL}$ of the juçara pulp extract. After 3 min of standing in the dark, $2.4 \mathrm{~mL}$ of saturated $\mathrm{Na}_{2} \mathrm{CO}_{3}$ solution $(7.5 \%$ $\mathrm{m} / \mathrm{v}$ ) was added. After $1 \mathrm{~h}$ of standing in the absence of light, the absorbance was measured at $760 \mathrm{~nm}$ using a spectrophotometer. TPC was determined using a standard curve of gallic acid $(0-200 \mathrm{mg} / \mathrm{L})$, and the results are expressed in gallic acid equivalent $(\mathrm{mg}$ $\mathrm{GAE} / 100 \mathrm{~g}$ ) on a wet basis.

Antioxidant capacity by 2,2'-azino-bis(3ethylbenzothiazoline-6-sulfonic acid (ABTS) radical cation assay

The anti-free radical capacity was measured using the ABTS radical assay method. For the formation of the $\mathrm{ABTS}^{\cdot+}$ radical, a $7 \mathrm{mM}$ ABTS aqueous solution was added to a $2.45 \mathrm{mM}$ potassium persulfate solution. This mixture was kept in the dark at room temperature for 16 h. Thereafter, the absorbance of the mixture was adjusted to $0.700( \pm 0.02)$ at $734 \mathrm{~nm}$ by adding $80 \%$ ethanol (Re et al., 1999). The ABTS $^{++}$radical solution $(3.5 \mathrm{~mL})$ was added to $0.5 \mathrm{~mL}$ of each extract of the raw material. After letting the mixture react for $6 \mathrm{~min}$, the absorbance was measured. Trolox was used as the standard, and the results are expressed in Trolox equivalents ( $\mu \mathrm{mol}$ Trolox/g) on a wet basis.

\section{2,2-diphenyl-1-picrylhydrazyl (DPPH) radical scavenging capacity}

The antioxidant capacity was evaluated by reacting the antioxidant compounds of the juçara pulp extract with the stable radical $\mathrm{DPPH} \bullet$. The analysis was performed based on the methods reported by Brand-Williams et al. (1995), Oliveira et al. (2011), and Pukalskas et al. (2002) with modifications. An aliquot $(100 \mu \mathrm{L})$ of the extracts was added to the methanolic solution of $0.1 \mathrm{mM}$ DPPH $(1.0 \mathrm{~mL})$. The mixture was stirred in the dark, and after $15 \mathrm{~min}$, the absorbance was measured at $517 \mathrm{~nm}$. At the same time, the absorbance of a blank solution (methanol) was measured. The radicalscavenging capacity of the tested samples, expressed as a percentage of free radical scavenging ( $\% \mathrm{FRS})$, was calculated using Equation 1.

$\% \mathrm{FRS}=100-\left[\left(\mathrm{A}_{\mathrm{A}}-\mathrm{A}_{\mathrm{B}}\right) / \mathrm{A}_{\mathrm{C}}\right] \times 100$

Where: $\mathrm{A}_{\mathrm{A}}=$ absorbance of the sample; $\mathrm{A}_{\mathrm{B}}=$ absorbance of the extraction solvent (methanol); and $\mathrm{A}_{\mathrm{C}}=$ control absorbance (DPPH methanolic solution). 


\section{Colorimetric analysis}

The juçara pulp was characterized by the direct reflectance reading of the rectangular coordinate system "L*" (luminosity), "a*" (red and green intensity), and "b*" (yellow and blue intensity). The CIELAB color scale was used, with a $\mathrm{D}_{65}$ illuminator and a $10^{\circ}$ viewing angle, along with a colorimeter (Konica Minolta Sensing, CM-5, Japan). The values of "C*" (chromaticity or color saturation) and h (hue angle) were calculated from the values of $a^{*}$ and $b^{*}$ using Equations 2 and 3.

$C^{*}=\left[\left(a^{*}\right)^{2}+\left(b^{*}\right)^{2}\right]^{1 / 2}$

$h=\arctan \left(b^{*} / a^{*}\right)$

\section{Effect of different temperatures and ultrasonic power on juçara pulp extracts}

A previous complementary study was performed to determine the optimal conditions for extracting anthocyanins and phenolic compounds and determining their antioxidant capacity. Different extraction solvents (ethanol, methanol, and acetone) and concentrations $(41.7 \%-98.3 \%)$ and a solution to pulp ratio of $2.0-18$ $\mathrm{mL} / \mathrm{g}$ were evaluated through a Central Composite Rotational Design (CCRD). High extraction of bioactive compounds was observed using ethanol $50 \%(\mathrm{v} / \mathrm{v})$ combined with $15.6 \mathrm{~mL} / \mathrm{g}$ of solution to pulp ratio.

In the present study, ultrasonic power $(0 \mathrm{~W}$ as a control, $360 \mathrm{~W}$, and $900 \mathrm{~W}$ ) was evaluated together with the extraction temperatures $(25,32,39,46$, and $53{ }^{\circ} \mathrm{C}$ ) as summarized in Table 1 . Anthocyanins, total phenolic compounds, and other bioactive compounds responsible for the antioxidant capacity were extracted from the juçara pulp for 15 min using an ultrasound bath (UPL-10AE, CTA, Brazil) at a frequency of 25 $\mathrm{kHz}$, according to the method adapted from the study of Borges et al. (2011a). These parameters were defined according to the operational conditions of the equipment. The temperatures used in our study were also based on the study by Vieira et al. (2013), which were programmed in the bath ultrasound apparatus and monitored using a digital thermometer.

This experiment was conducted in a factorial scheme, three times and in duplicate. Data were subject to analysis of variance, regression analysis, and Tukey's test as applicable, at $5 \%$ significance.
Table 1:Variables and levels analyzed by ultrasoundassisted extraction of the juçara pulp.

\begin{tabular}{cccccc}
\hline Variables & \multicolumn{5}{c}{ levels } \\
\hline Power (Watts) & 0 & 360 & \multicolumn{2}{c}{900} \\
Temperature $\left({ }^{\circ} \mathrm{C}\right)$ & 25 & 32 & 39 & 46 & 53 \\
\hline
\end{tabular}

\section{RESULTS AND DISCUSSION}

\section{Physicochemical characterization and quantification of bioactive compounds found in juçara pulp}

The physicochemical characteristics of the juçara pulp are presented in Table 2. The values for $\mathrm{pH}$ (Barros et al., 2015; Oliveira et al., 2018), acidity (Ribeiro; Mendes; Pereira, 2011; Schulz et al., 2020), moisture content (Silva et al., 2013), and ash (Ribeiro; Mendes; Pereira, 2011; Schulz et al., 2020; Silva et al., 2013) were similar to those reported by other studies. The lipid and protein contents were slightly lower than those reported in another study (Vieira et al., 2013). The physicochemical composition and the content of bioactive compounds in fruits can be affected by several factors, including fruit maturation, cultivation practices, geographical origin, harvest conditions, and storage processes (Borges et al., 2011b; Carvalho et al., 2020; Kim; Jeong; Lee, 2003). As these factors are not controlled, they could explain the differences between the values obtained in the present study and those reported previously in the literature for the same fruit.

The total anthocyanin content determined in the present study (298.86 mg cyanidin-3-glucoside/100 g on a wet basis) was higher than that reported by Ribeiro et al. (2011) and Rufino et al. (2010) (235.80 e $111.00 \mathrm{mg}$ cyanidin-3-glucoside/100 g on a wet basis, respectively). Borges et al. (2011b) found different amounts of the pigment ( 72.50 to $409.85 \mathrm{mg} / 100 \mathrm{~g}$ ) in juçara pulp obtained from different regions, using an ultrasonic bath, and hexane and methanol as extracting solvents. We found that juçara pulp contains a high concentration of anthocyanins, which confers a dark color (Table 2). We also noticed a higher total phenolic content than that reported by Borges et al. (2011b) (684.00 mg GAE/100 g). The antioxidant capacity measured using the ABTS radical method was similar to that reported in another study that used an ultrasound bath and methanol as the extracting solvent (despite different values because of variations in extraction times and solid/liquid ratio) 
Table 2: Physicochemical characterization of juçara pulp.

\begin{tabular}{|c|c|}
\hline Physicochemical characteristics & $\begin{array}{c}\text { Average values } \\
\text { (Mean } \pm \text { standard deviation) }\end{array}$ \\
\hline $\mathrm{pH}$ & $5.06 \pm 0.04$ \\
\hline Titratable acidity (\% citric acid) & $0.19 \pm 0.01$ \\
\hline Water content (\%) & $89.64 \pm 0.24$ \\
\hline Ash (\%) & $0.39 \pm 0.01$ \\
\hline Lipids (\%) * & $3.33 \pm 0.08$ \\
\hline Proteins (\%) & $0.82 \pm 0.11$ \\
\hline Anthocyanins (mg cyanidin-3-glucoside/100 g) & $298.86 \pm 27.68$ \\
\hline Antioxidant capacity (ABTS) ( $\mu \mathrm{mol}$ Trolox/g) & $16.06 \pm 1.38$ \\
\hline Antioxidant capacity (DPPH) (\% FRS) & $53.02 \pm 1.36$ \\
\hline Phenolic compounds (mg GAE/100 g) & $1226.39 \pm 21.08$ \\
\hline$L^{*}$ & $10.57 \pm 0.22$ \\
\hline$a^{*}$ & $6.99 \pm 0.21$ \\
\hline$b^{*}$ & $-0.58 \pm 0.07$ \\
\hline$h^{\circ}$ & $355.22 \pm 0.46$ \\
\hline$C^{*}$ & $7.01 \pm 0.22$ \\
\hline
\end{tabular}

GAE: gallic acid equivalent; \% FRS: free radical scavenging.

All results were expressed on a wet basis; except lipids $\left({ }^{*}\right)$, expressed on a dry basis.

(Borges et al., 2011a). However, the antioxidant capacity of juçara measured using the DPPH method was higher than that reported by Duarte-Almeida et al. (2006) for Euterpe precatoria Martius. As discussed previously, environmental factors affect the content of bioactive compounds. In addition, the type and concentration of the extractor solvent and extraction methods used can also affect the quantification of compounds (Albuquerque et al., 2020; Borges et al., 2011a; Jin et al., 2019).

Anthocyanin compounds have gathered attention because of their vast range of possible applications, including their use as food colorants and functional additives in foodstuff (López et al., 2018). Therefore, the high contents of anthocyanins and phenolic compounds and their high antioxidant capacity makes juçara a plant of commercial interest, as reported in our previous studies (Lima et al., 2019a; Lima et al., 2019b). Additionally, the juçara pulp analyzed in the present study was superior to the pulp used in other studies in terms of phytochemical content and antioxidant capacity. This may be because the characteristics of fruits are affected by various factors such as soil, climate, crop management, exposure to the Sun, and stage of maturation (Nawaz et al., 2020; Patras et al., 2020). As demonstrated by Carvalho et al. (2019), when the content of bioactive compounds in the six genotypes of juçara from different ecological regions was evaluated, considerable physicochemical variations were observed.

Using high-performance liquid chromatography (Figure 1), the anthocyanins cyanidin-3-glucoside and cyanidin-3-rutinoside were identified in juçara pulp, with cyanidin-3-rutinoside being the major component. These anthocyanins were identified in the chromatogram by comparing the retention times of the peaks with their respective standards. Cyanidin-3-glucoside is particularly important because it is the most abundant anthocyanin found in nature, making it the standard for quantifying anthocyanin compounds (López et al., 2018). These compounds were also identified as the predominant anthocyanins in juçara (Brito et al., 2007), açaí (Schauss et al., 2006), and in the peel extract of juçara, which together accounted for more than $87 \%$ of the extract's total phenolic content (Garcia et al., 2019). In these studies and in the present study, cyanidin-3-rutinoside was present in higher concentrations than cyanidin-3-glucoside.

Regarding the color parameters, the juçara pulp showed low luminosity $\left(\mathrm{L}^{*}\right)$, indicating a color close to black. The $a^{*}$ coordinate, which indicates the intensity of green to red, was positive, indicating a tendency toward red color, while the $b^{*}$ coordinate, which pertains to the intensity of blue to yellow, was negative, indicating a 
tendency toward blue color. The chroma $\left(\mathrm{C}^{*}\right)$ followed the same tendency as the values of the $\mathrm{a}^{*}$ coordinate, indicating that the $\mathrm{a}^{*}$ parameter was more important for determining the chromaticity of the juçara pulp. The hue angle (h) of $355^{\circ}$ indicates that the tonality of juçara pulp was in the fourth quadrant in the CIELab color system (between blue and red). Such a high value (close to $360^{\circ}$ ) means that the pulp is dark red in color (Table 2).

\section{Effect of different temperatures and ultrasonic power on juçara pulp extracts}

Analysis of variance for the dependent variables anthocyanin content, total phenolic content, and the antioxidant capacity of juçara extracts obtained using UAE was performed. For anthocyanins, there was a significant effect due to the interaction between ultrasonic power and temperature. We attempted to determine a mathematical relationship between these factors; however, it was not possible to fit any model to the data. First-, second-, and third-degree polynomials were tested, and Tukey's multiple comparisons test was used to compare the different temperatures analyzed (Table 3 ). For greater extraction of anthocyanins, an ultrasonic power of $360 \mathrm{~W}$ and $900 \mathrm{~W}$ can be used at any temperature analyzed in the present study (Table 3). Extraction without the use of ultrasonic waves (power of $0 \mathrm{~W}$ ) can be performed at any temperature, except at $39{ }^{\circ} \mathrm{C}$, which results in less pigment extraction. Random experimental errors possibly contributed to the unexpected result at this temperature $\left(39^{\circ} \mathrm{C}\right)$. It was observed that 25 , 32,46 , and $53{ }^{\circ} \mathrm{C}$ can be applied to any ultrasonic power analyzed in the present study, and there was no significant difference $(p>0.05)$ between different temperatures, except $39^{\circ} \mathrm{C}$. Thus, considering the cost of the equipment and the goal of minimizing the cost of the extraction process and obtaining the extracts, we suggest that the extraction of anthocyanins from the juçara pulp should be performed without the use of ultrasonic waves at $25{ }^{\circ} \mathrm{C}$. At this temperature, there was no significant difference $(p>0.05)$ between different ultrasonic powers.

Vieira et al. (2013) also evaluated the effect of temperature on the extraction of bioactive compounds from juçara using an ultrasound bath, and similar to the present study, they did not find a significant difference in the content of anthocyanins or phenolic compounds extracted at different temperatures. This result corroborates the result reported by Rocha et al. (2018), wherein they compared the extraction of anthocyanins and phenolic compounds of juçara by conventional extraction and UAE using ethanol or water as the extracting solvent. The authors observed the same extraction efficiency of these compounds for both the extracting solvents and methods. The fact that the extraction of anthocyanins and phenolic compounds is independent of ultrasound power may be associated with the pulp used as a raw material. According to Vieira et al. (2013), juçara pulp contains small particles that are formed during the pulping process, with large surface areas that provide excellent contact with the extractive solvent, independent of the extraction process, which favors the extraction of bioactive compounds. However, Carrera et al. (2012) also applied different temperatures between 0 and $75^{\circ} \mathrm{C}$ in the extraction of anthocyanins and phenolic compounds from grapes using an ultrasound probe, and the authors found higher levels of anthocyanins when the extraction was performed at 10 and $20^{\circ} \mathrm{C}$. Celli et al. (2015) reported that a UAE bath is effective for the extraction of anthocyanins from haskap berries, using a low temperature and in a reasonable time of $20 \mathrm{~min}$. According to Mane et al. (2015), although UAE proved to be a helpful technology for anthocyanin extraction, a longer duration for extraction can destroy some bioactive compounds. Some studies have compared heat-assisted extraction (HAE) and UAE using an ultrasonic probe for extracting anthocyanins by changing different variables such as time, solvent, temperature, and ultrasonic power (Albuquerque et al., 2020; López et al., 2018; Pinela et al., 2019). There is no consensus about a better extraction method, but it is clear that it is important to use appropriate experimental designs to optimize the extraction conditions that can lead to the best results in terms of recovering target compounds (Pinela et al., 2019).

For total phenolic content, only ultrasonic power had a significant effect. A higher mean phenolic content ( $p$ $<0.05$ ) was observed when ultrasonic waves were not used, while ultrasonic waves at $360 \mathrm{~W}$ and $900 \mathrm{~W}$ yielded lower phenolic contents (Figure 2). Since not using ultrasonic waves favored the extraction of phenolic compounds, and the temperature did not affect the extraction efficiency significantly, we suggest that to obtain extracts rich in phenolic compounds, extraction should be performed without the use of ultrasonic waves and at any temperature used in the present study. However, considering the energy cost for increasing the temperature, we suggest that the extraction of phenolic compounds should be performed at $25^{\circ} \mathrm{C}$. This result contradicts that of Virot et al. (2010), who compared the extraction of phenolic compounds from apple pomace using the conventional method and a UAE bath and found a $20 \%$ increase in phenolic content when ultrasonic waves were used. However, UAE will not always improve the extraction of phenolic compounds. Using an ultrasonic probe, Qiao et al. (2013) analyzed 
the sonochemical effects of ultrasonic waves on seven phenolic acids in a model system and discovered that some compounds degraded after ultrasonic treatment. The nature of the solvent, temperature, liquid height, ultrasonic intensity, and duty cycle of the ultrasound exposure are important factors in phenolic acid degradation.
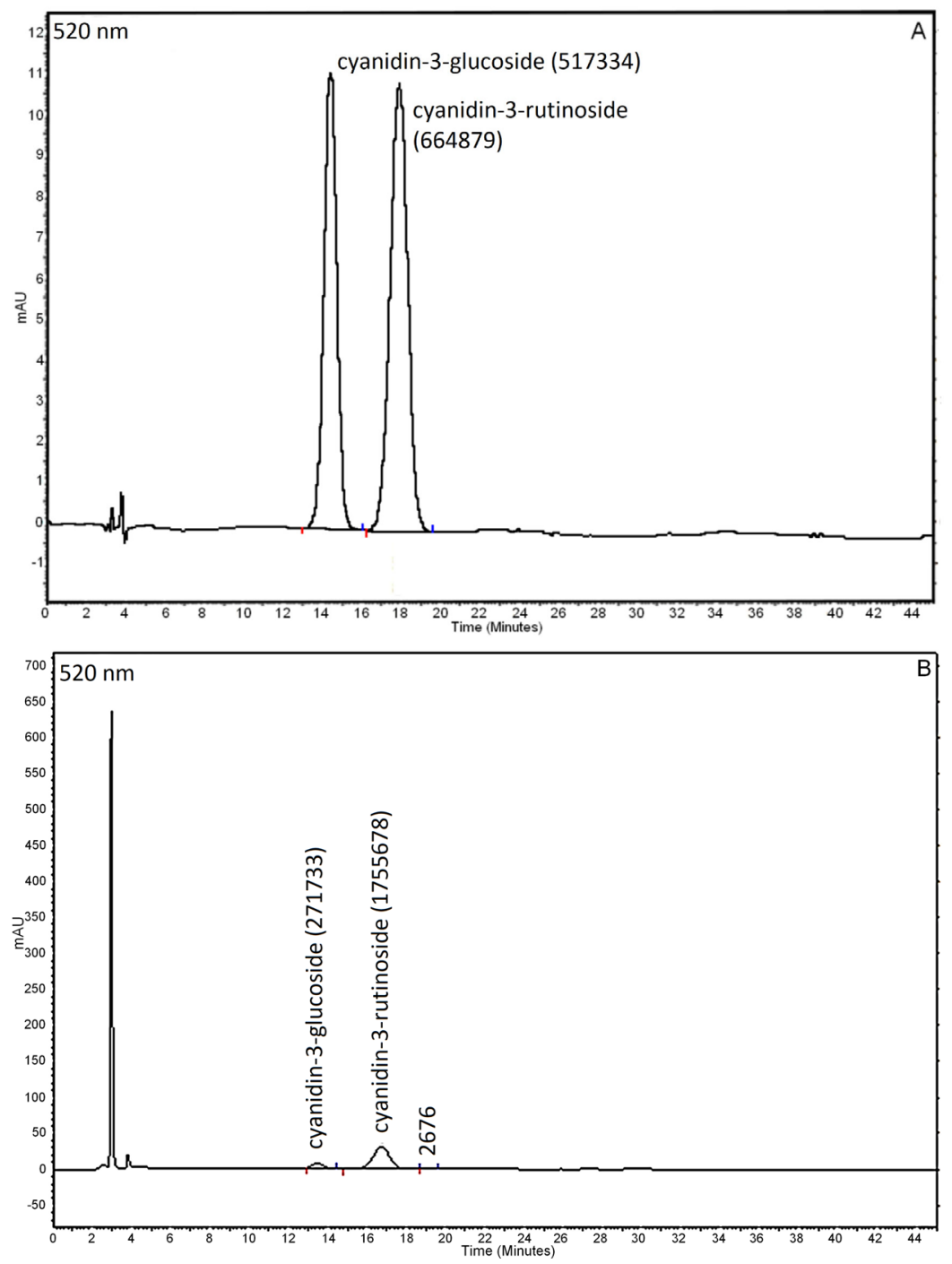

Figure 1: Chromatogram of anthocyanin standards: cyanidin 3-glucoside and cyanidin 3-rutinoside (A) and chromatogram of the juçara pulp (B).

Table 3: Anthocyanin content for juçara pulp extracts under ultrasound-assisted extraction: effect of temperatures and ultrasonic power.

\begin{tabular}{cllcll}
\hline & \multicolumn{1}{c}{$25^{\circ} \mathrm{C}$} & \multicolumn{1}{c}{$32^{\circ} \mathrm{C}$} & \multicolumn{1}{c}{$39^{\circ} \mathrm{C}$} & \multicolumn{1}{c}{$46^{\circ} \mathrm{C}$} & \multicolumn{1}{c}{$53^{\circ} \mathrm{C}$} \\
\hline $0 \mathrm{~W}$ & $269.57 \pm 12.16 \mathrm{aA}$ & $228.05 \pm 2.53 \mathrm{abA}$ & $190.92 \pm 13.48 \mathrm{bA}$ & $216.07 \pm 5.75 \mathrm{abA}$ & $230.62 \pm 14.49 \mathrm{abA}$ \\
$360 \mathrm{~W}$ & $270.07 \pm 2.44 \mathrm{aA}$ & $265.64 \pm 7.53 \mathrm{aA}$ & $281.04 \pm 12.92 \mathrm{aB}$ & $263.92 \pm 6.67 \mathrm{aA}$ & $282.64 \pm 11.07 \mathrm{aA}$ \\
$900 \mathrm{~W}$ & $262.39 \pm 9.14 \mathrm{aA}$ & $245.37 \pm 14.25 \mathrm{aA}$ & $259.65 \pm 10.16 \mathrm{aB}$ & $270.26 \pm 10.93 \mathrm{aA}$ & $265.47 \pm 5.53 \mathrm{aA}$ \\
\hline
\end{tabular}

Means followed by the same lowercase letter in rows did not differ $(p>0.05)$ by Tukey's test. Means followed by the same uppercase letter in columns did not differ $(p>0.05)$ by Tukey's test.

Results were expressed on mg cyanidin-3- glucoside/100 g of juçara pulp on a wet basis. 


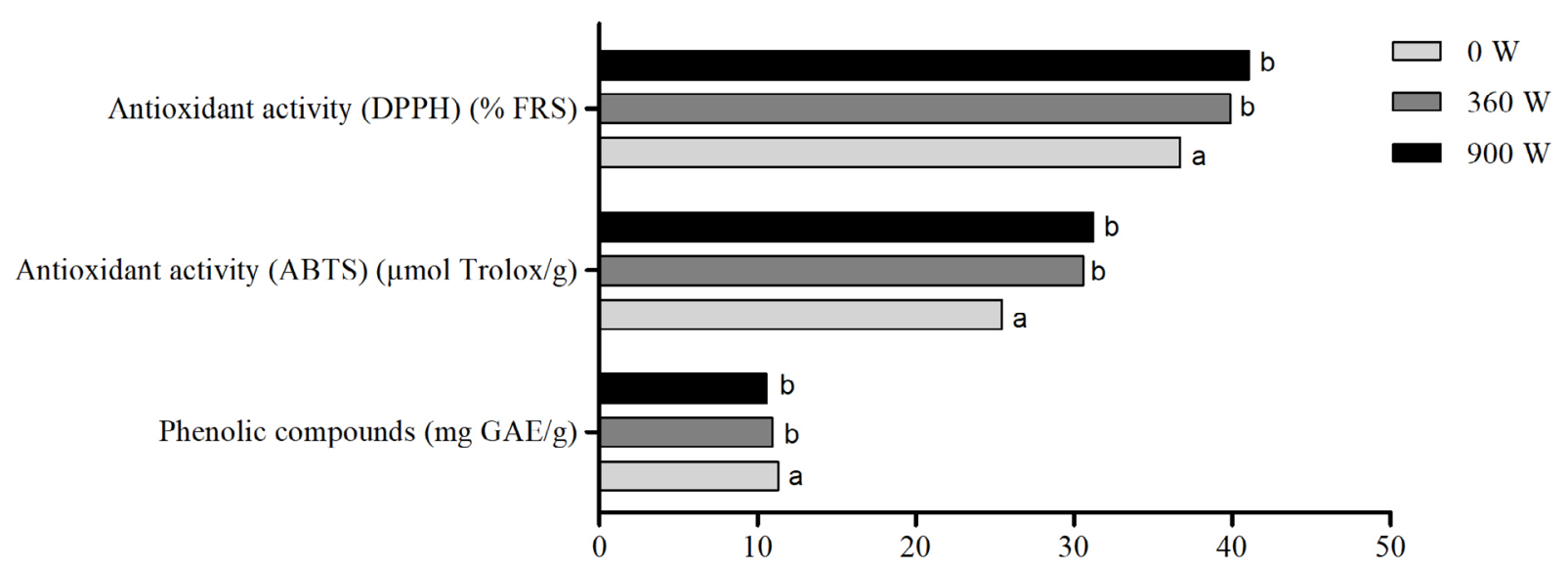

Figure 2: Total phenolic content and antioxidant capacity by radicals ABTS and DPPH of juçara extracts submitted to different ultrasonic power. (GAE: gallic acid equivalent; \%FRS: free radical scavenging).

Similarly, for the antioxidant capacity determined using the ABTS and DPPH methods, it was found that only using or not using ultrasonic waves had a significant effect on this variable. There was no significant difference $(p>0.05)$ between using 360 or $900 \mathrm{~W}$, but both yielded an extract with substantially higher antioxidant capacity compared to the extracts produced without ultrasonic waves (Figure 2), regardless of temperature. However, considering the operating cost, a temperature of $25^{\circ} \mathrm{C}$ and an ultrasonic power of $360 \mathrm{~W}$ is recommended.

While the antioxidant capacity was enhanced by using ultrasonic waves, extraction of phenolic compounds decreased when ultrasonic waves were used. One possible reason for this is that the juçara fruit may contain other non-phenolic compounds that can contribute to its antioxidant capacity. These non-phenolic compounds could be measured by ABTS and DPPH assays. In addition, the use of high-power ultrasonic waves increases cavitation, which is the formation, growth, and collapse of microbubbles in a liquid medium. Cavitation may favor the extraction of compounds that confer antioxidant capacity, such as ascorbic acid, as demonstrated by Um, Han and Lee (2018) and Le and Le (2012). The ABTS and DPPH methods, although widely used in food matrices, have limited specificity (De Oliveira et al., 2016). As the juçara extract was not purified in the present study, it may contain compounds that are extractable using the hydroethanolic solution. Thus, compounds other than anthocyanins and phenolic compounds can be extracted using ultrasound and may have contributed to the antioxidant capacity.

\section{CONCLUSIONS}

Based on the optimization of the extraction of bioactive compounds (total phenolic compounds and anthocyanins) from the juçara pulp, it is not necessary to use ultrasonic waves, and the extraction can be performed at $25{ }^{\circ} \mathrm{C}$ to reduce operational costs. To obtain extracts with a high antioxidant capacity, extracting using an ultrasonic bath at $360 \mathrm{~W}$ at $25^{\circ} \mathrm{C}$ is recommended.

\section{ACKNOWLEDGEMENTS}

This work was supported by Coordenação de Aperfeiçoamento de Pessoal de Nível Superior - Brazil (CAPES) - Finance Code 001, Fundação de Amparo à Pesquisa e Inovação do Estado do Espírito Santo (FAPES) and Conselho Nacional de Desenvolvimento Científico e Tecnológico (CNPq). Authors thank CAPES and FAPES for master's scholarship and CNPq for financial support (Grant number: 478246/2013-7).

\section{REFERENCES}

ABDEL-MOEMIN, A. R. Switching to black rice diets modulates low-density lipoprotein oxidation lipid measurements in rabbits. The American Journal of the Medical Sciences, 341(4):318-324, 2011

ADJÉ, F. et al. Optimization of anthocyanin, flavonol and phenolic acid extractions from Delonix regia tree flowers using ultrasound-assisted water extraction. Industrial Crops and Products, 32(3):439-444, 2010. 
ALBUQUERQUE, B. R. et al. Anthocyanin-rich extract of jabuticaba epicarp as a natural colorant: Optimization of heat- and ultrasound-assisted extractions and application in a bakery product. Food Chemistry, 316:e126364, 2020.

ASSOCIATION OF OFFICIAL ANALYTICAL CHEMISTRY - AOAC. Official Methods of Analysis of AOAC International. 20th Ed, Rockville, Maryland, USA. 2016. 3172p.

BARROS, E. C. M. et al. Efeitos da pasteurização sobre características físico-químicas, microbiológicas e teor de antocianinas da polpa de juçaí (Euterpe edulis Martius). Revista Teccen, 8(1):21-26, 2015.

BARROSO, M. E. S. et al. Phytochemical profile of genotypes of Euterpe edulis Martius - Juçara palm fruits. Food Research International, 116:985-993, 2019.

BONFIGLI, M. et al. Comparison between conventional and ultrasound-assisted techniques for extraction of anthocyanins from grape pomace. Experimental results and mathematical modeling. Journal of Food Engineering, 207:56-72, 2017.

BORGES, G. S. C. et al. Optimization of the extraction of flavanols and anthocyanins from the fruit pulp of Euterpe edulis using the response surface methodology. Food Research International, 44(3):708-715, 2011 a.

BORGES, G. S. C. et al. Chemical characterization, bioactive compounds, and antioxidant capacity of jussara (Euterpe edulis) fruit from the Atlantic Forest in southern Brazil. Food Research International, 44(7):2128-2133, 2011 b.

BRAND-WILLIAMS, W. et al. Use of a free radical method to evaluate antioxidant activity. LWT-Food Science and Technology, 28(1):25-30, 1995.

BRITO, S. E. et al. Anthocyanins present in selected tropical fruits: Acerola, jambolão, jussara, and guajiru. Journal of Agricultural and Food Chemistry, 55(23):9389-9394, 2007.

BRUNNER, G. Supercritical fluids: Technology and application to food processing. Journal of Food Engineering, 67(12):21-33, 2005.

CARRERA, C. et al. Ultrasound assisted extraction of phenolic compounds from grapes. Analytica Chimica Acta, 732:100-104, 2012.

CARVALHO, A. G. S. et al. Anthocyanins from jussara (Euterpe edulis Martius) extract carried by calcium alginate beads pre-prepared using ionic gelation. Powder Technology 345:283-291, 2019.
CARVALHO, F. M. et al. Pitanga and grumixama extracts: Antioxidant and antimicrobial activities and incorporation into cellulosic films against Staphylococcus aureus. Research, Society and Development, 9(11):e1759119362, 2020.

CELLI, G. B. et al. Optimization of ultrasound-assisted extraction of anthocyanins from haskap berries (Lonicera caerulea L.) using response surface methodology. Ultrasonics Sonochemistry, 27:449-455, 2015.

CHEN, L. et al. Ultrasound-assisted extraction and characterization of anthocyanins from purple corn bran. Journal of Food Processing and Preservation, 42(1):e13377, 2017.

CORBIN, C. et al. Development and validation of an efficient ultrasound assisted extraction of phenolic compounds from flax (Linum usitatissimum L.) seeds. Ultrasonics Sonochemistry, 26:176-185, 2015.

DE OLIVEIRA, I. R. et al. Evaluation of potential interfering agents on in vitro methods for the determination of the antioxidant capacity in anthocyanin extracts. International Journal of Food Science \& Technology, 52(2):511-518, 2016.

DUARTE-ALMEIDA, J. M. et al. Avaliação da atividade antioxidante utilizando sistema $\beta$-caroteno/ácido linoléico e método de seqüestro de radicais DPPH. Food Science and Technology, 26(2):446-452, 2006.

FERNANDES, F. A. N. et al. Ultrasound-assisted extraction of anthocyanins and phenolics from jabuticaba (Myrciaria cauliflora) peel: Kinetics and mathematical modeling. Journal of Food Science and Technology, 57(6):23212328, 2020.

FRANCIS, F. J. Analysis of anthocyanins in foods. In: MARKAKIS, P. Anthocyanins as food colors. Academic Press, p.181207, 1982.

GARCIA, J. A. A. et al. Chemical composition and biological activities of Juçara (Euterpe edulis Martius) fruit by-products, a promising underexploited source of high-added value compounds. Journal of Functional Foods, 55:325-332, 2019.

GAROFULIĆ, I. E. et al. The effect of microwave assisted extraction on the isolation of anthocyanins and phenolic acids from sour cherry Marasca (Prunus cerasus var. Marasca). Journal of Food Engineering, 117(4):437-442, 2013.

GIUSTI, M. M.; WROLSTAD, R. E. Anthocyanins. Characterization and measurement with UV-Visible spectroscopy. In: WROLSTAD, R. E. Current Protocols in food analytical chemistry. New York:John Wiley \& Sons, p. F1.2.1- F1.2.13, 2001. 
HOGAN, S. et al. Antiproliferative and antioxidant properties of anthocyanin-rich extract from açaí. Food Chemistry, 118(2):208-214, 2010.

INADA, K. O. P. et al. Screening of the chemical composition and occurring antioxidants in jabuticaba (Myrciaria jaboticaba) and jussara (Euterpe edulis) fruits and their fractions. Journal of Functional Foods, 17:422-433, 2015.

IVANOVIC, J. et al. Antioxidant properties of the anthocyanincontaining ultrasonic extract from blackberry cultivar "Cacanska Bestrna". Industrial Crops and Products, 53:274-281, 2014.

JIANG, B. Evaluation of bioactive compounds of black mulberry juice after thermal, microwave, ultrasonic processing, and storage at different temperatures. Food Science and Technology International, 21(5):392-399, 2020.

JIN, Y. et al. Natural antioxidant of rosemary extract used as an additive in the ultrasound-assisted extraction of anthocyanins from lingonberry (Vaccinium vitis-idaea L.) pomace. Industrial Crops \& Products, 138:e111425, 2019.

KIM, D. O.; JEONG, S. W.; LEE, C. Y. Antioxidant capacity of phenolic phytochemicals from various cultivars of plums. Food Chemistry, 81(3):321-326, 2003.

$\mathrm{KOBI}, \mathrm{H}$. B. et al. Organic and conventional strawberries: Nutritional quality, antioxidant characteristics and pesticide residues. Fruits, 73(1):39-47, 2018.

LE, H. V.; LE, V. V. M. Comparison of enzyme-assisted and ultrasound-assisted extraction of vitamin $C$ and phenolic compounds from acerola (Malpighia emarginata DC.) fruit. International Journal of Food Science \& Technology, 47(6):1206-1214, 2012.

LIMA, E. M. F. et al. Spray-dried microcapsules of anthocyaninrich extracts from Euterpe edulis M. as an alternative for maintaining color and bioactive compounds in dairy beverages. Journal of Food Science and Technology, 56(9):4147-4157, 2019a.

LIMA, E. M. F. et al. Effect of encapsulating agent and drying air temperature on the characteristics of microcapsules of anthocyanins and polyphenols from juçara (Euterpe edulis Martius). International Food Research Journal, 26(2):607-617, 2019b.

LÓPEZ, C. J. et al. Optimization and comparison of heat and ultrasound assisted extraction techniques to obtain anthocyanin compounds from Arbutus unedo L. fruits. Food Chemistry, 264:81-91, 2018.
MANE S. et al. Effect of ultrasound on the extraction of total anthocyanins from purple majesty potato. Ultrasonics Sonochemistry, 27:509-514, 2015.

NAWAZ, R. et al. Impact of climate variables on fruit internal quality of Kinnow mandarin (Citrus nobilis Lour x Citrus deliciosa Tenora) in ripening phase grown under varying environmental conditions. Scientia Horticulturae, 265:e109235, 2020.

OLIVEIRA, A. F. A. et al. Non-thermal combined treatments in the processing of açai (Euterpe oleracea) juice. Food Chemistry, 265:57-63, 2018.

OLIVEIRA, A. G.; COSTA, M. C. D.; ROCHA, S. M. B. M. Functional benefits of açai berry in the prevention of cardiovascular diseases. Journal of Amazon Health Science, 1(1):1-10, 2015.

OLIVEIRA, D. S. et al. Vitamina C, carotenoides, fenólicos totais e atividade antioxidante de goiaba, manga e mamão procedentes da Ceasa do Estado de Minas Gerais. Acta Scientiarum- Health Sciences, 33(1):8998, 2011.

OLIVEIRA, M. S. P. Biologia floral do açaizeiro em Belém, PA: Embrapa Amazônia Oriental. Belém Boletim Técnico, 8:1-26, 2002.

PATRASA, A. et al. Effect of thermal processing on anthocyanin stability in foods; mechanisms and kinetics of degradation. Food Science \& Technology, 21(1):3-11, 2020.

PINELA, J. et al. Optimization of heat- and ultrasound-assisted extraction of anthocyanins from Hibiscus sabdariffa calyces for natural food colorants. Food Chemistry, 275:309-321, 2019.

PORTO, C.; PORRETTO, E.; DECORTI, D. Comparison of ultrasound-assisted extraction with conventional extraction methods of oil and polyphenols from grape (Vitis vinifera L.) seeds. Ultrasonics Sonochemistry, 20(4):1076-1080, 2013.

PRIPREM, A. et al. Anthocyanin complex improves stability with in vitro localized UVA protective effect. Current Bioactive Compounds, 13(4):333-339, 2017.

PUÉRTOLAS, E. et al. Pulsed-electric-field-assisted extraction of anthocyanins from purple-fleshed potato. Food Chemistry, 136(3-4):1330-1336, 2013.

PUKALSKAS, A. et al. Identification of radical scavengers in sweet grass (Hierochloe odorata). Journal of Agricultural and Food Chemistry, 50(10):2914-2919, 2002. 
QIAO, L. et al. Sonochemical effects on free phenolic acids under ultrasound treatment in a model system. Ultrasonics Sonochemistry, 20(4):1017-1025, 2013.

QIN, H. et al. Volatiles, polysaccharides and total polyphenols in Chinese rose tea infusions and their antioxidant activities. Journal of Food Processing and Preservation, 42(1):e13323, 2018.

RE, R. et al. Antioxidant activity applying an improved ABTS radical cation decolorization assay. Advances in Free Radical Biology and Medicine, 26(9-10):1231-1237, 1999.

RIBEIRO, L. O.; MENDES, M. F.; PEREIRA, C. S. S. Avaliação da composição centesimal, mineral e teor de antocianinas da polpa de juçaí (Euterpe edulis Martius). Revista Teccen, 4(3):5-16, 2011.

ROCHA, J. D. C. G. et al. Optimization of ultrasound-assisted extraction of phenolic compounds from jussara (Euterpe edulis M.) and blueberry (Vaccinium myrtillus) fruits. Food Science and Technology, 38(1):45-53, 2018.

RUFINO, M. S. M. et al. Bioactive compounds and antioxidant capacities of 18 nontraditional tropical fruits from Brazil. Food Chemistry, 121:996-1002, 2010.

SAITO, T. et al. Jabuticaba (Myrciaria cauliflora) peel extract increases bioactive compounds in petit-suisse cheese. International Food Research Journal, 26(1):277-285, 2019.

SCHAUSS, A. G. et al. Phytochemical and nutrient composition of freeze-dried amazonian palm berry, Euterpe oleraceae Mart. (Acai). Journal of Agricultural and Food Chemistry, 54(22):8598-8603, 2006.
SCHULZ, M. et al. Composition and potential health effects of dark-colored underutilized Brazilian fruits - A review. Food Research International, 137:e109744, 2020.

SHIRSATH, S. R.; SONAWANE, S. H.; GOGATE, P. R. Intensification of extraction of natural products using ultrasonic irradiations - A review of current status. Chemical Engineering and Processing: Process Intensification, 53:10-23, 2012.

SILVA, P. P. M. et al. Physical, chemical, and lipid composition of Juçara (Euterpe edulis Mart.) Pulp. Brazilian Journal of Food and Nutrition, 24(1):7-13, 2013.

SINGLETON, V. L.; ROSSI, J. A. Colorimetry of total phenolics with phosphomolybdic-phosphotungstic acid reagents. American Journal for Enology and Viticulture, 16(1):144158, 1965.

UM, M.; HAN, T. H.; LEE, J. W. Ultrasound-assisted extraction and antioxidant activity of phenolic and flavonoid compounds and ascorbic acid from rugosa rose (Rosa rugosa Thunb.) fruit. Food Science and Biotechnology, 27(2):375-382, 2018.

VIEIRA, G. S. et al. Chemical and economic evaluation of natural antioxidant extracts obtained by ultrasoundassisted and agitated bed extraction from jussara pulp (Euterpe edulis). Journal of Food Engineering, 119(2):196204, 2013.

VIROT, M. et al. Towards the industrial production of antioxidants from food processing by-products with ultrasound-assisted extraction. Ultrasonics Sonochemistry, 17(6):1066-1074, 2010. 